\title{
KLAUSULA BAKU DALAM PERJANJIAN ENDORSEMENT DIKAITKAN DENGAN ASAS KEBEBASAN BERKONTRAK
}

\author{
Alya Yudityastri \\ E-mail: alyayudit@gmail.com \\ Mahasiswa Fakultas Hukum Universitas Sebelas Maret Surakarta \\ Suraji \\ E-mail: suraji.esha@gmail.com \\ Dosen Fakultas Hukum Universitas Sebelas Maret Surakarta
}

\begin{abstract}
This article aims to find out the validity of standard agreements in general and specially on endorsement agreement. Validity of the endorsement agreement is reviewed from the Civil Code, Law Number 19 of 2016 concerning Amendments to Law No. 11 of 2008 concerning Information and Electronic Transactions, Law Number 8 of 1999 concerning Consumer Protection. In addition to knowing the suitability of the endorsement agreement that contains a standard contract clause with the principle of freedom of contract. Legal writing in this study uses research normative law with the statutory approach and conceptual approach. Research result it is known that the endorsement agreement is an example of a standard agreement with through the electronic system is in accordance with the provisions of the validity of the agreement according to the Civil Code, Law Number 19 of 2016 concerning Amendments to Law No. 11 of 2008 concerning Information and Electronic Transactions, Law Number 8 of 1999 concerning Protection Consumer. Standard agreement if it is related to the principle of freedom of contract is still being the debate over the suitability. Some are of the view that standard agreements are included in the terms of the endorsement agreement, are not in accordance with the principle of freedom of contract because of intermediaries the parties do not have a balanced bargaining position. Others argue that the agreement is in accordance with the principle of freedom of contract provided there is no clause exoneration in it.
\end{abstract}

Keywords: Endorsement; Endorsement Contract; Standard Contract Clauses; Principle of Contract Freedom

\begin{abstract}
Abstrak
Artikel ini bertujuan untuk mengetahui keabsahan perjanjian baku secara umum dan khususnya pada perjanjian endorsement. Keabsahan perjanjian endorsement ditinjau dari KUHPerdata, Undang-Undang Nomor 19 Tahun 2016 Tentang Perubahan Atas Undang-Undang No. 11 Tahun 2008 tentang Informasi dan Transaksi Elektronik, Undang-Undang Nomor 8 Tahun 1999 tentang Perlindungan Konsumen. Selain itu untuk mengetahui kesesuaian perjanjian endorsement yang memuat klausula kontrak baku dengan asas kebebasan berkontrak. Penulisan hukum dalam penelitian ini menggunakan penelitian hukum normatif dengan pendekatan perundang-undangan dan pendekatan konseptual. Hasil penelitian diketahui bahwa perjanjian endorsement yang merupakan salah satu contoh perjanjian baku dengan melalui sistem elektronik telah sesuai dengan ketentuan keabsahan perjanjian menurut KUHPerdata, Undang-Undang Nomor 19 Tahun 2016 Tentang Perubahan Atas Undang-Undang No. 11 Tahun 2008 tentang Informasi dan Transaksi Elektronik, Undang-Undang Nomor 8 Tahun 1999 tentang Perlindungan Konsumen. Kesesuaian perjanjian baku dengan asas kebebasan berkontrak masih menjadi perdebatan. Beberapa berpandangan bahwa perjanjian baku termasuk di dalamnya perjanjian endorsement, tidak sesuai dengan asas kebebasan berkontrak karena di antara para pihaknya tidak memiliki posisi tawar yang seimbang. Sebagian lainnya berpendapat bahwa perjanjian tersebut telah sesuai dengan asas kebebasan berkontrak apabila tidak terdapat klausula eksonerasi di dalamnya.
\end{abstract}

Kata Kunci: Endorsement; Perjanjian Endorsement; Perjanjian Baku; Asas Kebebasan Berkontrak; 


\section{A. Pendahuluan}

Berkembangnya informasi serta teknologi penunjangnya menjadikan teknologi informasi mempunyai peran hampir di seluruh bagian kehidupan manusia, di antaranya pada bidang ekonomi, yang mana sistem demikian disebut sebagai electronic commerce atau e-commerce. Dengan melakukan usaha melalui e-commerce, penjual harus mencari cara untuk terus meningkatkan minat beli masyarakat. Salah satu cara yang digunakan yaitu penjual harus menggunakan jasa orang lain atau pihak lain untuk mempromosikan usahanya yang dikenal dengan endorsement. Pihak lain yang dimaksud tersebut harus yang memiliki banyak penggemar atau pengikut di media sosial yang disebut dengan endorser, maka selayaknya seorang endorser adalah public figure atau selebriti (Isetyowati A\&Raden Besse K, 2019: 75).

Penggunaan endorser atau pihak yang ingin mengiklankan produk merupakan upaya untuk meningkatkan citra sebuah merek dan sebagai publisitas produk atau jasa tersebut. Dalam praktiknya, pemilik bisnis akan melakukan penawaran kepada orang-orang terkenal seperti artis atau selebritis untuk mengiklankan barang/jasa yang merupakan bisnisnya. Pihak artis ini kemudian disebut sebagai endorser, sedangkan pihak yang ingin mengiklankan barang/jasa miliknya disebut sebagai endorsee.

Perjanjian yang dibuat dalam suatu perjanjian endorsement berisi beberapa klausula yang bisa berbeda-beda dari setiap endorser. Sebagian besar perjanjian endorsement hanya berisi klausula yang dibuat oleh satu pihak yaitu endorser. Para endorser tersebut sudah menyiapkan isi kontrak yang kemudian diberikan kepada calon endorsee. Pihak yang akan mengiklankan produknya biasanya tidak diberikan kesempatan untuk bernegosiasi. Mereka hanya bisa menyetujui maupun menolak isi kontrak yang telah dibuat oleh endorser.

Hukum perjanjian di Indonesia menganut asas kebebasan dalam hal membuat perjanjian yang kemudian dikenal dengan asas kebebasan berkontrak. Asas kebebasan berkontrak mengandung arti bahwa setiap orang mempunyai kebebasan untuk mengikatkan dirinya pada orang lain. Satu hal yang patut diperhatikan adalah bahwa asas tersebut adalah mengasumsikan ada posisi tawar yang seimbang di antara para pembuat kontrak (Lina Jamilah, 2012: 227).

Kebebasan berkontrak berpangkal pada kedudukan kedua belah pihak yang sama kuatnya, memiliki posisi tawar (bargaining position) yang sama, sehingga masing-masing pihak berkedudukan sebagai mitra kontrak (Muhammad Arifin, 2011:283). Kenyataannya, di kontrak perjanjian endorsement salah satu pihak telah membuat beberapa klausula perjanjian terlebih dahulu tanpa adanya ruang untuk negosiasi dari pihak lainnya. Berdasarkan kondisi yang telah dijelaskan diatas, artikel ini dimaksudkan untuk mengkaji keabsahan perjanjian endorsement yang memuat klausula baku di dalamnya dan mengkaji kesesuaiannya dengan asas kebebasan berkontrak

\section{B. Metode Penelitian}

Jenis penelitian yang digunakan penulis adalah penelitian hukum normatif. Penelitian hukum normatif memiliki definisi yang sama dengan penelitian doktrinal yaitu penelitian yang didasarkan bahan-bahan hukum primer dan sekunder. Bahan-bahan hukum tersebut disusun secara sistematis, dikaji, dan ditarik suatu kesimpulan dalam hubungannya dengan masalah yang diteliti (Peter Mahmud Marzuki, 2014:95).

\section{Hasil Penelitian dan Pembahasan}

Perjanjian endorsement yang dibuat oleh endorser dan endorsee melalui media sosial instagram dilakukan melalui media elektronik seperti Whatsapp, Line, ataupun direct message Instagram. Edmon Makarim menjelaskan bahwa transaksi melalui media elektronik yaitu para pihak melakukan hubungan hukum yang dituangkan melalui bentuk perjanjian yang dilakukan secara elektronik, dengan memadukan jaringan dari sistem informasi berbasis komputer dan sistem komunikasi yang berdasarkan jaringan dan jasa telekomunikasi yang selanjutnya difasilitasi oleh keberadaan jaringan komputer global (Edmon Makarim, 2005:255). 
Perjanjian dalam KUHPerdata dapat ditemukan dalam Pasal 1313 KUHPerdata, yang menyebutkan bahwa "Suatu Perjanjian adalah suatu perbuatan dengan mana satu orang atau lebih mengikatkan dirinya terhadap satu orang atau lebih". Perbuatan yang disebutkan dalam Pasal 1313 KUHPerdata hendak menjelaskan bahwa perjanjian hanya mungkin terjadi jika ada suatu perbuatan nyata, baik dalam bentuk ucapan, maupun tindakan secara fisik, dan tidak hanya dalam bentuk pikiran semata-mata (Kartini Muljadi, Gunawan Widjaja, 2002:7). Terdapat beberapa macam perjanjian di Indonesia. Tidak semua perjanjian yang ada diatur dalam suatu undangundang secara khusus walaupun ada pula perjanjian yang diatur dalam suatu undang-undang.

Berdasarkan Pasal 1313 KUHPerdata, sebuah tindakan yang mana satu pihak atau lebih mengikat untuk satu atau lebih orang, sehingga lahir hak dan kewajiban di antara mereka yang harus dipenuhi oleh mereka. Termasuk juga endorser dan endorsee yang harus mememuhi hak dan kewajiban di antara mereka sehingga apabila ada di antara mereka yang tidak memenuhinya, memenuhi tetapi tidak sesuai yang diperjanjikan, atau tidak memenuhi sama sekali, maka pihak tersebut dinyatakan telah wanprestasi atau ingkar janji

Menurut ketentuan yang diatur dalam KUHPerdata tersebut, secara a contrario dapat dikatakan bahwa pada dasarnya kesepakatan dianggap terjadi pada saat perjanjian dibuat oleh para pihak, kecuali dapat dibuktikan bahwa kesepakatan tersebut terjadi karena adanya kekhilafan, paksaan maupun penipuan. Sebagaimana ditentukan dalam Pasal 1321 KUHPerdata, yang berbunyi: "Tiada sepakat yang sah apabila sepakat itu diberikan karena kehilafan, atau diperolehnya dengan paksaan atau penipuan". Walaupun dikatakan tiada sepakat yang sah, tetapi tidak berarti perjanjian itu batal karena sebenarnya telah terjadi kesepakatan, hanya saja kesepakatan yang telah dicapai tersebut mengalami kecacatan karena kesepakatannya terjadi karena kekhilafan, paksaan atau penipuan (Ahmad Miru \& Sakka Pati, 2008:69).

Pasal 1320 KUHPerdata mengatur mengenai syarat sahnya perjanjian. Untuk sahnya suatu perjanjian diperlukan empat syarat sebagai berikut:

1) Sepakat mereka yang mengikatkan dirinya;

2) Kecakapan untuk membuat suatu perikatan;

3) Suatu hal tertentu;

4) Suatu sebab yang halal.

Merujuk pada Pasal 1320 KUHPerdata mengenai syarat-syarat sahnya suatu perjanjian, syarat yang pertama dapat diartikan bahwa para pihak yang terlibat dalam perjanjian harus sepakat atau setuju mengenai hal-hal pokok dari perjanjian tersebut (P.N.H. Simanjuntak, 2009:334). Pada pasal 1321 KUHPerdata menentukan bahwa kata sepakat tidak sah apabila diberikan karena kekhilafan atau diperoleh dengan paksaan dan penipuan.

Syarat sahnya perjanjian yang kedua adalah adanya kecakapan untuk membuat sesuatu. Pasal 1330 KUHPerdata menentukan bahwa setiap orang adalah cakap untuk membuat perikatan, kecuali undang-undang menentukan bahwa ia tidak cakap. Mengenai orang-orang yang tidak cakap dalam membuat suatu perjanjian dapat kita lihat dalam Pasal 1330 KUHPerdata, yaitu sebagai berikut:

1) Anak yang belum dewasa;

2) Orang yang ditaruh di bawah pengampuan;

3) Perempuan yang telah kawin dalam hal-hal yang ditentukan undang-undang.

Ketentuan ketiga menjadi hapus karena adanya Undang-Undang Nomor 1 Tahun 1974 tentang Perkawinan. Karena dalam Pasal 31 Undang-Undang ini menentukan bahwa hak dan kedudukan suami dan istri adalah sama atau seimbang.

Maksud dari suatu hal tertentu dapat disimpulkan dari Pasal 1332 dan Pasal 1333 KUHPerdata. Pasal 1332 menyebutkan "Hanya barang yang dapat diperdagangkan saja yang dapat menjadi pokok perjanjian", sedangkan Pasal 1333 KUHPerdata menyebutkan "Suatu perjanjian harus mempunyai pokok berupa suatu barang yang sekurang-kurangnya ditentukan jenisnya. Jumlah barang itu tidak perlu pasti, asal saja jumlah itu kemudian dapat ditentukan atau dihitung." 
Suatu sebab yang halal dapat diartikan bahwa isi dari perjanjian tersebut tidak dilarang oleh undang-undang dan juga tidak bertentangan dengan kesusilaan dan ketertiban umum. Hal ini disimpulkan dari pasal 1337 KUHPerdata. Selain itu, Pasal 1335 KUHPerdata menyebutkan bahwa "suatu persetujuan tanpa sebab, atau dibuat berdasarkan suatu sebab yang palsu atau yang terlarang, tidaklah mempunyai kekuatan.", artinya perjanjian yang dibuat tanpa sebab atau dibuat karena suatu sebab yang palsu atau terlarang adalah tidak mempunyai kekuatan hukum.

Dapat disimpulkan dari pasal-pasal tersebut di atas bahwa suatu perjanjian bebas dibuat oleh para pihak dengan jenis apapun, kepada siapapun, bebas menentukan isinya, dan juga bentuk dari perjanjian. Namun dari semua ketentuan tersebut, tetap perjanjian harus sesuai dengan ketentuan perundang-undangan, dan tidak melanggar kesusilaan dan ketertiban umum.

Perjanjian endorsement walaupun disepakati melalui media online namun selayaknya tetap mengacu pada syarat-syarat menurut KUHPerdata. Berdasarkan data yang diperoleh penulis, dapat disimpulkan bahwa sebagian besar perjanjian endorsement telah memenuhi syarat sahnya suatu perjanjian menurut KUHPerdata seperti yang telah dijabarkan di atas.

Para pihak dalam perjanjian endorsement sudah tentu merupakan endorser dan endorsee yang terlibat langsung dalam kegiatan endorsement tersebut. Meskipun ada beberapa endorser yang menggunakan pihak ketiga berupa management artis atau individu yang dipercaya sebagai pihak ketiga. Mengenai kecakapan dalam membuat suatu perjanjian, sudah tentu ini terpenuhi. Pasalnya antara para pihak pasti cakap dalam membuat perjanjian. Walaupun ada juga pihak yang belum dewasa, misalnya endorser yang belum cukup umur, perjanjian yang dilakukan sudah pasti melalui pihak ketiga, bisa melalui manager maupun orang tuanya sendiri.

Suatu hal tertentu dalam perjanjian endorsement yaitu berupa pembelian jasa endorser oleh pihak endorsee. Pastinya di dalam perjanjian tersebut terdapat objek yang diperdagangkan, dapat berpa barang maupun jasa. Perjanjian endorsement memuat suatu hal yang halal, artinya tidak memperdagangkan barang yang tidak sesuai dengan ketentuan hukum. Beberapa perjanjian endorsement memuat klausul yang secara langsung mengatakan bahwa pihak endorser tidak menerima barang palsu, obat-obatan terlarang, dan barang lain yang tidak dibenarkan oleh hukum.

Kontrak elektronik menurut Pasal 1 angka 17 Undang-Undang Nomor 19 Tahun 2016 Tentang Perubahan Atas Undang-Undang Nomor 11 Tahun 2008 tentang Informasi dan Transaksi Elektronik menyebutkan bahwa kontrak elektronik adalah perjanjian para pihak yang dibuat melalui sistem elektronik. Pasal 18 ayat (1) UU ITE juga menyebutkan bahwa: "Transaksi Elektronik yang dituangkan ke dalam Kontrak Elektronik mengikat para pihak.". Perjanjian endorsement merupakan jenis kontrak elektronik yang lahir karena adanya penawaran dan penerimaan. Perjanjian endorsement tersebut mengikat bagi dua pihak yaitu endorser dan endorsee.

Perjanjian elektronik yang telah disepakati oleh kedua belah pihak secara online dapat menjadi dasar dan alat bukti hukum yang sah. Hal ini didasarkan pada Pasal 5 Undang-Undang ITE yang dirumuskan sebagai berikut:

(1) Informasi Elektronik dan/atau Dokumen Elektronik dan/atau hasil cetaknya merupakan alat bukti hukum yang sah;

(2) Informasi dan/atau Dokumen Elektronik dan/atau hasil cetaknya sebagaimana dimaksud pada ayat (1) merupakan perluasan dari alat bukti yang sah sesuai dengan Hukum Acara yang berlaku di Indonesia;

(3) Informasi Elektronik dan/atau Dokumen Elektronik dinyatakan sah apabila menggunakan Sistem Elektronik sesuai dengan ketentuan yang diatur dalam Undang-Undang ini.

Berdasarkan Undang-Undang ITE seperti yang telah dijelaskan di atas, dapat disimpulkan bahwa perjanjian endorsement sah dan memiliki kekuatan hukum. Perjanjian endorsement merupakan salah satu bentuk perjanjian elektronik. Hampir semua perjanjian endorsement tidak berbentuk tertulis di atas kertas melainkan tertulis dalam media elektronik.

Klausula baku dalam suatu perjanjian juga diatur dalam Undang Undang-Undang Nomor 8 Tahun 1999 tentang Perlindungan Konsumen, yang selanjutnya akan disebut UU Perlindungan 
Konsumen. Pada Pasal 1 angka 10 UU Perlindungan Konsumen menyebutkan definisi klausula baku adalah "Setiap aturan atau ketentuan dan syarat-syarat yang telah dipersiapkan dan ditetapkan terlebih dahulu secara sepihak oleh pelaku usaha yang dituangkan dalam suatu dokumen dan/atau perjanjian yang mengikat dan wajib dipenuhi konsumen." (Zakiyah, 2011:71).

Biasanya suatu klausul baku dalam suatu perjanjian dilakukan oleh pihak yang memiliki posisi tawar lebih kuat dibandingkan dengan konsumen. Dikaitkan dengan perjanjian endorsement, biasanya endorser memiliki posisi yang lebih kuat dalam posisi tawar, dan endorsee memiliki posisi sebagai konsumen yang memiliki posisi tawar lebih lemah. Ketidakseimbangan ini diatur lebih lanjut dalam Pasal 18 UU Perlindungan Konsumen tentang ketentuan pencantuman klausula baku.

UU Perlindungan Konsumen mengatur beberapa larangan dalam pencantuman klausula baku pada suatu perjanjian. Tepatnya pada Pasal 18 ayat (1) UU Perlindungan Konsumen yang menyatakan bahwa pelaku usaha dalam menawarkan barang dan/atau jasa yang ditujukan untuk diperdagangkan dilarang membuat dan/atau mencantumkan klausula baku pada setiap dokumen dan/atau perjanjian apabila:

1) Menyataan pengalihan tanggung jawab pelaku usaha;

2) Menyatakan bahwa pelaku usaha berhak menolak menyerahkan kembali barang yang dibeli konsumen;

3) Menyatakan bahwa pelaku usaha berhak menolak penyerahan kembali uang yang dibayarkan atas barang dan/atau jasa yang dibeli oleh konsumen;

4) Menyatakan pemberian kuasa dari konsumen kepada pelaku usaha baik secara langsung maupun tidak langsung untuk melakukan segala tindakan sepihak yang berkaitan dengan barang yang dibeli oleh konsumen secara angsuran;

5) Mengatur perihal pembuktian atas hilangnya kegunaan barang atau pemanfaatan jasa yang dibeli oleh konsumen;

6) Memberi hak kepada pelaku usaha mengurangi manfaat jasa atau mengurangi harta kekayaan konsumen yang menjadi objek jual beli jasa;

7) Menyatakan tunduknya konsumen kepada peraturan yang berupa aturan baru, tambahan, lanjutan dan/atau pengubahan lanjutan yang dibuat sepihak oleh pelaku usaha dalam masa konsumen memanfaatkan jasa yang dibelinya;

8) Menyatakan bahwa konsumen memberi kuasa kepada pelaku usaha pembebanan hak tanggungan, hak gadai, atau hak jaminan terhadap barang yang dibeli oleh konsumen secara angsuran.

Pasal 18 ayat (2) UU Perlindungan Konsumen menyatakan bahwa: pelaku usaha dilarang mencantumkan klausula baku yang letak atau bentuknya sulit terlihat atau tidak dapat dibaca secara jelas, atau yang pengungkapannya sulit dimengerti.

Kekuatan hukum perjanjian endorsement dapat dilihat dari keabsahan perjanjian itu sendiri. Keabsahan suatu perjanjian seperti yang telah dijelaskan bahwa dapat dilihat dari beberapa perundang-undangan. Salah satunya keabsahan suatu perjanjian harus sesuai dengan ketentuanketentuan dalam KUHPerdata. Pasal 1320 merupakan acuan utama dalam menilai keabsahan suatu perjanjian. Dimana pasal tersebut menjelaskan mengenai syarat-syarat sahnya perjanjian.

Hukum Perdata mengenal beberapa prinsip dasar yang harus diterapkan dalam penyusunan kontrak sehingga akan terhindar dari unsur-unsur yang dapat merugikan para pihak pembuat suatu kontrak yang mereka sepakati. Prinsip tersebut salah satunya adalah Asas Kebebasan Berkontrak (Syahmin AK, 2011:4). Udin Silalahi menyebutkan bahwa asas kebebasan berkontrak bagi setiap individu memiliki dua pengertian sekaligus, yaitu kebebasan melakukan perjanjian dan kebebasan membuat isi perjanjian (M. Udin Silalahi, 2003:92).

Asas kebebasan berkontrak sebenarnya merupakan kelanjutan asas kesederajatan para pihak sebagai dasar hubungan keperdataan dan kemudian membedakannya dengan hubungan kepublikan yang bersifat atasan dan bawahan (M Faiz mufidi, 2008:24). Kebebasan berkontrak 
memberikan hak bagi setiap subyek hukum untuk dapat mengikatkan diri sebagai salah satu pihak dalam suatu kontrak. Fungsi kontrak sebagai wadah berlangsungnya peralihan hak dan kewajiban dalam berbagai perjanjian dapat berlangsung dengan lancar dengan adanya asas ini. Pihak-pihak yang mengikatkan diri dalam suatu kontrak berarti menjadikan kontrak tersebut sebagai undangundang bagi dirinya sendiri dan hubungan yang timbul dari kontrak tersebut adalah hubungan hukum (Silvia Riyani, 2011:83).

Perjanjian endorsement yang sering mencantumkan klausula baku apabila dikaitkan dengan asas kebebasan berkontrak dapat dikatakan sudah sesuai. Hanya saja ada beberapa hal yang mengakibatkan perjanjian endorsement melanggar asas kebebasan berkontrak. Dikatakan melanggar apabila suatu perjanjian endorsement memuat klausula eksonerasi atau klausula eksemsi.

Rijken mengatakan klausula eksonerasi adalah klausul yang dicantumkan dalam suatu perjanjian yang mana satu pihak menghindarkan diri untuk memenuhi kewajibannya dengan mengganti rugi seluruhnya atau terbatas, yang terjadi karena ingkar janji atau perbuatan melawan hukum (Ahmadi Miru, 2007:40). Klausula eksonerasi ini dapat terjadi atas kehendak satu pihak yang dituangkan dalam suatu perjanjian secara individual atau secara massal. Yang bersifat massal ini telah dipersiapkan terlebih dahulu dan diperbanyak dalam bentuk formulir, yang dinamakan perjanjian baku (Mariam Darus Badrulzaman, 1994:47).

Lina Jamilah mengatakan bahwa perjanjian standar/baku belum dapat dikatakan memenuhi sepenuhnya asas kebebasan berkontrak, karena dalam perjanjian tersebut isi perjanjian terdapat klausula yang dibakukan, tetap dan tidak dapat diadakan perundingan lagi, atau ketiadaan pengetahuan tentang isi kontrak, maupun ketiadaan atau kekurangan pilihan bebas dalam menentukan isi perjanjian dan atau ketentuan yang secara tidak wajar sangat memberatkan bagi salah satu pihak, dalam hal ini pihak yang menerima penawaran (Lina Jamilah, 2012:241).

Meskipun asas kebebasan memberi ruang kebebasan dalam menentukan jenis perjanjian apa yang dilakukan, perjanjian baku merupakan perjanjian sepihak maka cenderung berat sebelah dan merugikan bagi pihak yang lemah. Perjanjian baku pada dasarnya memang merugikan, akan tetapi agar kedudukan konsumen setara dengan pelaku usaha perlu memperhatikan pembatasan dari perjanjian baku. Selain itu asas kebebasan juga diberikan batasan oleh KUH Perdata, karena dinilai kurang memenuhi unsur keadilan (M. Roesli, Sarbini, Bastianto Nugroho, 2019:7).

Adanya perbedaan pendapat di kalangan ahli tidak membuat eksistensi dari perjanjian baku hilang. Perjanjian baku lahir karena kebutuhan masyarakat karena masyarakat menginginkan halhal yang bersifat pragmatis. Dalam perjanjian baku khususnya perjanjian endorsement, endorsee dapat menolak atau menerima dan menandatangani atau tidak menandatangani. Artinya jika endorsee menerima isi dari perjanjian tersebut maka secara tidak langsung ia terikat dengan endorser. Timbul hak dan kewajiban antara kedua pihak. Namun apabila pihak endorsee tidak menyetujui isi perjanjian tersebut, ia dapat menolak sehingga secara otomatis perjanjian tidak dilaksanakan.

Perjanjian endorsement yang merupakan perjanjian baku sebagian besar tidak bertentangan dengan substansi dalam asas kebebasan berkontrak. Perjanjian ini menjadi tidak sesuai apabila terdapat klausula eksonerasi dalam isi perjanjiannya. Hal ini dikarenakan dengan adanya klausula eksonerasi pasti kedua belah pihak memiliki posisi yang tidak diperbolehkan yakni satu pihak diuntungkan dan pihak lainnya dirugikan.

\section{Simpulan}

Berdasarkan hasil penelitian yang telah dilakukan oleh penulis, maka dapat ditarik kesimpulan:

1. Perjanjian endorsement yang merupakan perjanjian baku sesuai dengan ketentuan-ketentuan dalam beberapa peraturan perundang-undangan yang mengatur mengenai perjanjian baku. Menurut KUHPerdata, Undang-Undang Nomor 19 Tahun 2016 tentang perubahan atas Undang-Undang Nomor 11 Tahun 2008 tentang Informasi dan Transaksi Elektronik, Undang- 
Undang Nomor 8 Tahun 1999 tentang Perlindungan Konsumen. Perjanjian baku sah dan memiliki kekuatan hukum. Berdasarkan perundang-undangan diatas, perjanjian endorsement merupakan perjanjian baku berbasis elektronik yang sah dan telah memenuhi syarat sahnya perjanjian menurut KUHPerdata.

2. Terdapat beberapa pandangan yang berbeda mengenai kesesuaian perjanjian baku dengan asas kebebasan berkontrak. Beberapa ahli berpendapat bahwa perjanjian baku melanggar asas kebebasan berkontrak karena adanya posisi yang tidak seimbang di antara para pihak. Ada pula pendapat lain yang menyebutkan perjanjian baku telah sesuai dengan asas kebebasan berkontrak karena sejatinya tidak harus memiliki posisi tawar yang mutlak sama, hanya saja tidak merugikan salah satu pihak. Menurut penulis, perjanjian endorsement telah sesuai dengan asas kebebasan berkontrak, hanya saja ada beberapa hal yang menyebabkan perjanjian tersebut tidak sesuai dengan asas kebebasan berkontrak, yaitu apabila ada klausula eksonerasi di dalamnya.

\section{E. Saran}

Berdasarkan pemaparan kesimpulan yang disampaikan di atas, maka penulis mengajukan beberapa saran sebagai berikut:

1. Mengingat semakin banyaknya praktik endorsement, seharusnya endorsee atau pihak yang mengiklankan produk/jasa sejak awal perjanjian meminta pencantuman klausul mengenai sanksi yang akan diterima endorser apabila endorser terbukti tidak memenuhi prestasi. Contohnya apabila selebgram terlambat dalam mengunggah gambar atau video di akun Instagram pribadinya maka endorsee berhak mendapat ganti rugi. Bagi endorser seharusnya membuat jadwal kapan akan mengambil atau mengunggah gambar atau video di akun pribadinya agar dapat memenuhi prestasinya, sehingga tidak ada pihak yang dirugikan.

2. Untuk pihak endorser atau pihak pemilik bisnis dalam membuat perjanjian baku diharapkan untuk mempelajari lebih lanjut mengenai klausul-klausul baku yang boleh dicantumkan dan yang tidak boleh dicantumnkan, sehingga pada pelaksanaannya para pihak sama-sama diuntungkan dengan perjanjian endorsement yang telah disepakati bersama. Tidak ada pihak yang posisinya lebih kuat atau pihak lain yang posisinya lebih lemah. Tujuannya tentu untuk memberikan kesetaraan terhadap para pihak yang terikat dalam perjanjian ini.

\section{F. Daftar Pustaka}

Ahmadi Miru \& Sakka Pati. 2008. Hukum Perikatan Penjelasan Makna Pasal 1233 sampai 1456 BW. Jakarta: PT RajaGrafindo Persada

Ahmadi Miru. 2007. Hukum Kontrak Perancangan Kontrak. Jakarta: PT Raja Grafindo Perkasa.

Edmon Makarim. 2005. Pengantar Hukum Telematika Suatu Kompilasi. Jakarta: Rajawali Press.

Isetyowati Andayani \& Raden Besse Kartoningrat. 2019. Perlindungan Hukum terhadap Artis dalam Perjanjian Endorsement. Jurnal Hukum STHG. Volume 2 Nomor 2, Agustus 2019.

Kartini Muljadi dan Gunawan Widjaja. 2004. Perikatan yang Lahir dari Perjanjian. Jakarta: PT Raja Grafindo Persada

Kartini Muljadi dan Gunawan Widjaja. 2002. Perikatan yang Lahir dari Perjanjian. Jakarta: PT Raja Grafindo Persada

Lina Jamilah. 2012. Asas Kebebasan Berkontrak dalam Perjanjian Standar Baku. Syiar Hukum, Fakultas Hukum UNISBA. Volume XIII Nomor 1, Maret-Agustus 2012.

Muhammad Arifin. 2011. Penyalahgunaan Keadaan sebagai Faktor Pembatas Kebebasan Berkontrak. Jurnal Ilmu Hukum. Volume 14, Nomor 2, September 2011. 
Mariam Darus Badrulzaman. 1980. Perjanjian Baku (Standard) Perkembangannya di Indonesia. Bandung: Alumni

M Faiz Mufidi. 2008. Disertasi: Perjanjian Alih Teknologi dalam Bisnis Franchise sebagai Sarana Pengembangan Hukum Ekonomi.

M Roesli, dkk. 2019. Kedudukan Perjanjian Baku dalam Kaitannya dengan Asas Kebebasan Berkontrak. DiH: Jurnal IImu Hukum. Volume 15 Nomor 1, Februari 2019 - Juli 2019

M. Udin Silalahi. 2003. Dasar Hukum Obligation to Contract. Jurnal Hukum Bisnis. Volume 22, Nomor 2.

Peter Mahmud Marzuki. 2014. Penelitian Hukum. Jakarta: Pranamedia Group

P. N. H Simanjuntak. 2009. Pokok-pokok Hukum Perdata Indonesia. Jakarta: Djambatan

Silvia Riyani. 2011. "Tinjauan Yuridis Asas Kebebasan Berkontrak dalam Perjanjian Baku Pengadaan Jasa antara Bank dengan Vendor”. Tesis. Yogyakarta: FH UGM

Syahmin, A K. 2011. Hukum Kontrak Internasional. Jakarta: PT Raja Grafindo Persada.

Zakiyah. 2011. Hukum Perjanjian Teori dan Perkembangannya. Yogyakarta: Pustaka Felicha. 